\title{
声呐多传感器观测资料数据融合的一种深度学习 算法
}

\author{
李启虎 ${ }^{1,2^{*}}$ ，卫羽华 ${ }^{1,2}$, 薛山花 ${ }^{1}$
}

1. 中国科学院声学研究所, 北京 100190

2. 中国科学院大学, 北京 100049

* 通信作者. E-mail: lqh@mail.ioa.ac.cn

收稿日期: 2018-02-27； 接受日期: 2018-05-28; 网络出版日期: 2018-12-12

摘要 声呐多传感器观测资料的数据融合问题是声呐设计中的一个重要课题. 对于多基阵的声呐信 号处理系统, 面临的问题往往不仅是单个基阵多传感器的数据融合问题, 还有多个基阵的数据融合 问题. 本文的研究基于数据融合的基本规则, 即任何形式的数据融合, 从统计平均观点来说, 总体观 测误差绝不大于任何单个传感器或单个基阵的观测误差. 观测资料的增加从统计平均意义来说, 只 会带来好处, 即使有垃圾资料的加入。这一结论对于人工智能领域中的深度学习来说, 具有类似结 果. 文中提出一种用于数据融合的深度学习算法. 对于独立的或相关的观测资料进行最佳的线性融 合, 剔除野值, 进行决策级的分块数据融合, 以获得统计平均意义上最小误差的结果. 系统计算机模 拟表明, 对于受随机干扰的观测数据, 采用野值过滤和数据融合的深度学习方法, 能够使决策级误差 显著降低.

关键词 声呐信号处理, 多传感器观测, 数据融合, 深度学习

\section{1 引言}

多传感器观测数据的融合问题是声呐信号处理中的重要问题, 尤其是对于多平台、多基地的声呐 系统. 声呐设计者所面临的往往不是一个基阵的多传感器数据, 而是多个基阵的多传感器数据. 因而 使声呐系统的数据融合问题变得更加复杂 ${ }^{[1]}$.

雷达或声呐的数据融合或数据关联, 基于一个最基本的要求, 就是不管参与数据融合的单元数量 有多少, 数据相关程度有多大, 数据融合的最终结果从统计平均意义上来说, 必须具有最小的估计误 差, 就是比任何单独参与数据融合过程的个别输入的估计误差要小 $[2 \sim 6]$.

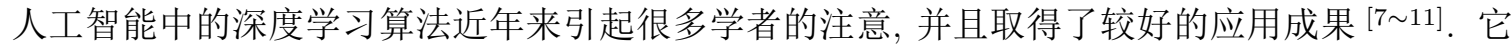
假定在输入数据层和最终判决层的结果之间存在若干隐蔽层, 神经网络的算法就存在于这些隐蔽层之

\footnotetext{
引用格式: 李启虎, 卫虫华, 薛山花. 声呐多传感器观测资料数据融合的一种深度学习算法. 中国科学: 信息科学, 2018, 48: 16141621, doi: 10.1360/N112018-00042

Li Q H, Wei C H, Xue S H. A deep learning algorithm for multiple observation data fusion in sonar system (in Chinese). Sci Sin Inform, 2018, 48: 1614-1621, doi: 10.1360/N112018-00042
} 


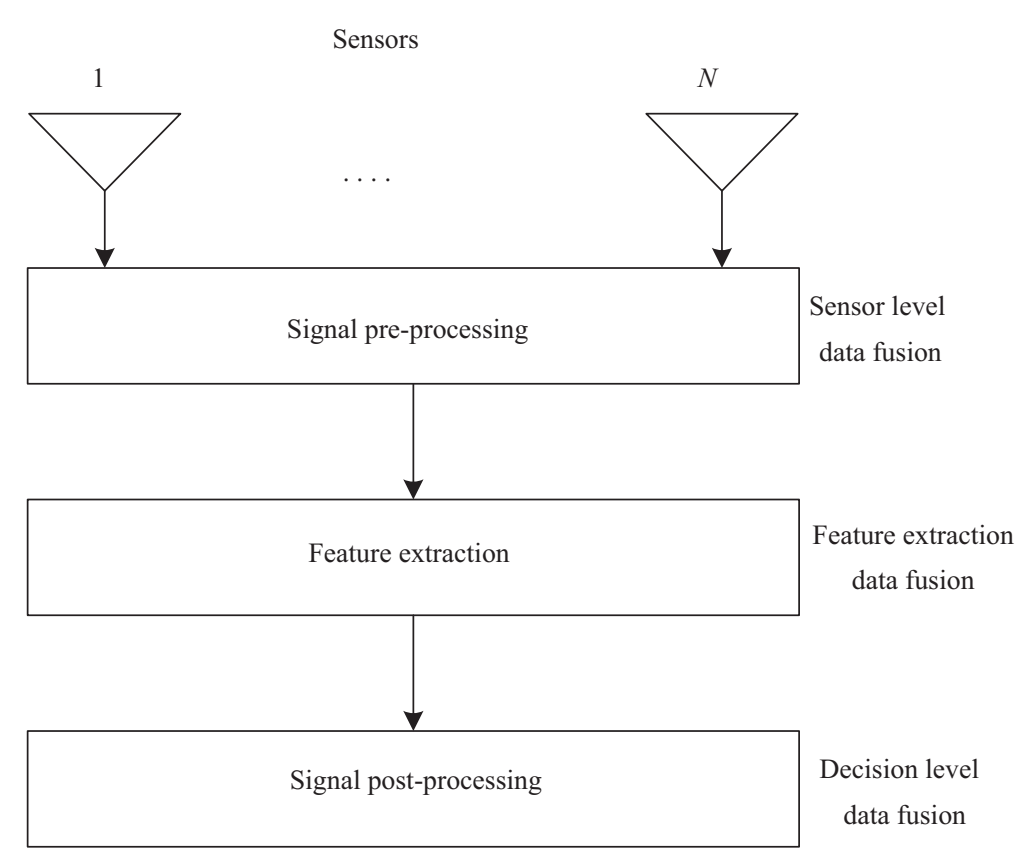

图 1 数据融合的分类

Figure 1 Three level of data fusion

中. 只要数据量足够大, 经过训练、学习的决策结果就有可能接近或达到人工智能的水平, 并且估计误 差随数据量的增加而降低. 这一特性有可能在数据融合中得到应用.

作为一种特殊的信号处理系统, 声呐数据融合通常分为 3 个不同层次, 即传感器级、特征提取级 和决策级 ${ }^{[1]}$. 本文研究决策级数据融合的问题, 即多个渠道己经有对目标参数或特征的判断, 要求系 统对这些不同的判断做出最终的融合和决策. 深度学习算法可以在这一决策中发挥很好的作用. 不管 多输入的资料是相互独立的还是互相关联的, 我们总可以求出一种最优的线性融合, 使统计平均意义 上的误差降到最小.

本文讨论的是一种可以用数值表征的决策, 而不是一般意义上的信息融合, 如目标分类识别, 因为 分类识别可以归入另一类非数字表征的深度学习中, 例如语音识别中对发言者性别或年龄的判断, 通 常是特征提取级的融合判断.

在计算机系统模拟中, 以目标方位估计为例, 对受到随机干扰的 300 批估计进行随机处理, 剔除 野值, 进行分块训练求出新的估计值, 取得了较好的效果. 如果以 20 个为一批进行分块处理, 估计误 差可以降低到原来的十分之一左右.

\section{2 声呐信号处理系统中的数据融合问题}

图 1 给出了与声呐信号处理有关的数据融合问题的框图. 一般把数据融合分为 3 级, 即传感器 级、特征提取级和决策级, 它们分别对应于信号处理系统的预处理部分、波束形成及处理 (特征提取) 部分和后处理部分.

对于现代数字式声呐, 来自多传感器的数据, 有时候不单是一个基阵的数据, 还可能是多平台、多 基阵的数据, 所以要处理融合问题, 可能更加复杂. 


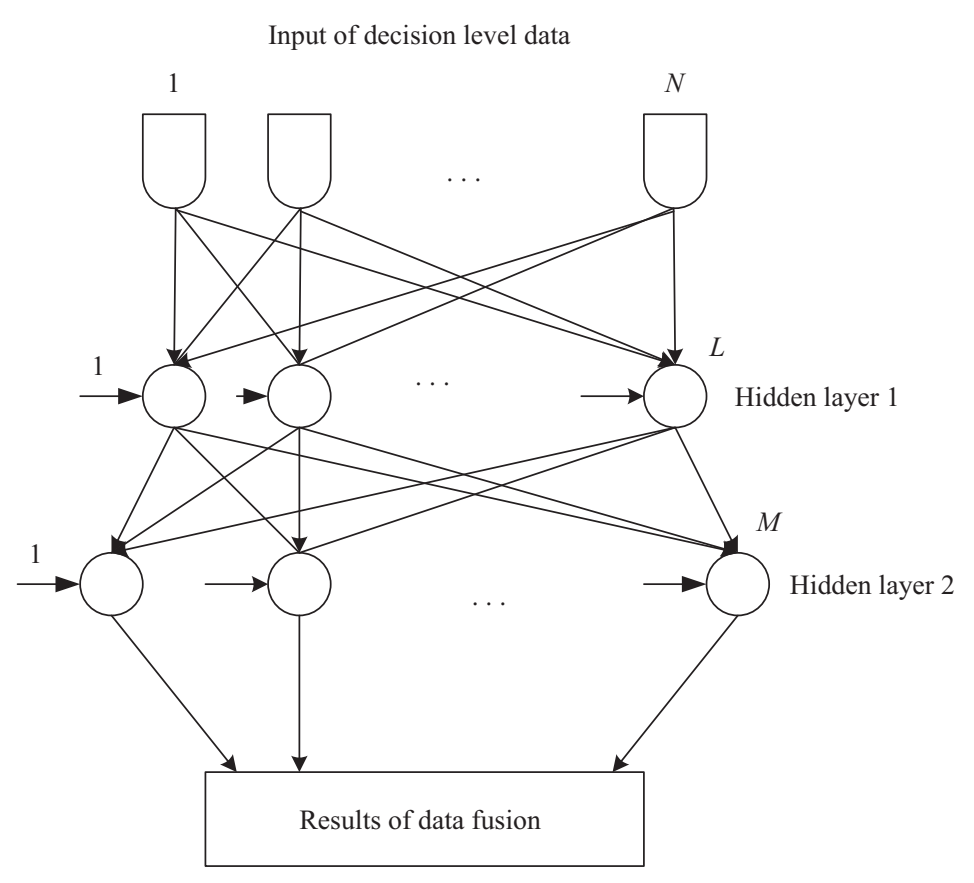

图 2 决策级数据融合的神经网络模型

Figure 2 Model of artificial neural network for decision level data fusion

本文讨论的是决策级数据融合, 即不同的 $N$ 个判决系统已对观测对象的某一参数 (例如目标方 位) 作出判决. 并且, 这个判决可以用数字来表征, 比如, 第 $i$ 个判决为 $x_{i}, i=1, \ldots, N$, 然后要求对 $x_{1}, \ldots, x_{N}$ 进行数据融合, 给出最后的决策.

当然, 数据融合还可以从另一个侧面来理解. 那就是, 如果判决结果无法用数字来表征, 比如目标 分类识别问题就是如此, 那么就要寻求别的方法来解决这类问题. 在语言识别中已经有不少尝试, 用于 判断发言者的性别或年龄. 这可以认为是信息融合范畴的课题 ${ }^{[11]}$.

我们仅限于讨论一类可以用数字来表征的数据融合问题. 其基本问题是: 如果待观测目标的真值 为 $\theta$, 第 $i$ 个观测结果是 $x_{i}$, 并且假定

$$
\mathrm{E}\left[x_{i}\right]=\theta, \quad i=1, \ldots, N,
$$

其中 $\mathrm{E}$ 表示对随机变量或随机向量求期望值. 我们要找到一个新的决策结果,

$$
x_{\text {new }}=f\left(x_{1}, \ldots, x_{N}\right), \quad \mathrm{E}\left[x_{\text {new }}\right]=\theta,
$$

并且使 $x_{\text {new }}$ 的观测误差小于任何一个 $x_{i}$ 的观测误差, 也就是

$$
\operatorname{Var}\left[x_{\text {new }}\right] \leqslant \operatorname{Var}\left[x_{i}\right], \quad i=1, \ldots, N .
$$

在人工神经网络理论中, 在输入 (决策级数据 $x_{1}, \ldots, x_{N}$ ) 和输出 $x_{\text {new }}$ 之间, 假设有一个或多个 隐蔽层, 见图 2 .

隐蔽层通过对输入数据的学习、训练, 经过调整系统的参数和反馈信息, 得出最后的判决.

由于隐蔽层是未知的信号处理机制, 我们暂时还无法求出其具体算法, 但根据最后判决的分析, 可 以逐步逼近隐含在隐蔽层的算法. 
一般认为, 在第 1 层的输入数据向量 $\boldsymbol{x}$ 和输出判决 $y$ 之间, 存在如下的函数关系:

$$
y=f\left(\boldsymbol{\omega}^{\mathrm{T}} \boldsymbol{x}+b\right),
$$

其中, $\boldsymbol{\omega}$ 表示隐蔽层的加权系数向量. $\mathrm{T}$ 表示矩阵或向量的转置运算. $b$ 是一个待定参数, 需要通过对 输入数据的学习和训练才能确定. 现在还没有直接的证据, 证明函数 $f(\cdot)$ 是线性的还是非线性的, 但 是有相当多的实例证明, 形式为 $\boldsymbol{\omega}^{\mathrm{T}} \boldsymbol{x}+b$ 的自变量, 确实能达到非常满意的结果 ${ }^{[7 \sim 11]}$.

多传感器的数据融合存在一种最佳线性融合算法, 不管是独立的观测资料还是相关的观测资料, 都可以找到一种数据融合结果, 使得新的估计具有最小估计误差 ${ }^{[5,6]}$.

概括起来讲, 就是如果待估计参数是 $\theta$, 而观测资料是 $x_{i}, i=1, \ldots, N$, 并且已知这种估计是无偏 的, 即 $\mathrm{E}\left[x_{i}\right]=\theta, i=1, \ldots, N$, 以向量表示

$$
\boldsymbol{x}=\left[x_{1}, \ldots, x_{N}\right]^{\mathrm{T}},
$$

寻求加权系数

$$
\boldsymbol{\omega}^{\mathrm{T}}=\left[\omega_{1}, \ldots, \omega_{N}\right], \quad \sum_{i=1}^{N} \omega_{i}=1
$$

令

$$
x_{\text {new }}=\boldsymbol{\omega}^{\mathrm{T}} \boldsymbol{x}
$$

使得

$$
\boldsymbol{I}=\mathrm{E}\left[\boldsymbol{\omega}^{\mathrm{T}}(\boldsymbol{x}-\mathrm{E} \boldsymbol{x})\right]^{2}
$$

极小 ( $\mathrm{E} \boldsymbol{x}$ 是 $\boldsymbol{x}$ 的均值), 约束条件是

$$
\boldsymbol{\omega}^{\mathrm{T}} \boldsymbol{U}=1
$$

其中, $\boldsymbol{U}^{\mathrm{T}}=[1, \ldots, 1]$. 可以把式 (8) 改写为

$$
\boldsymbol{I}=\boldsymbol{\omega}^{\mathrm{T}} \boldsymbol{R}_{x x} \boldsymbol{\omega}
$$

其中

$$
\boldsymbol{R}_{x x}=\mathrm{E}\left[(\boldsymbol{x}-\mathrm{E} \boldsymbol{x})(\boldsymbol{x}-\mathrm{E} \boldsymbol{x})^{\mathrm{T}}\right]
$$

是输入向量 $\boldsymbol{x}$ 的相关矩阵, 在观测资料相互独立的情况下, $\boldsymbol{R}_{x x}$ 就是一个对角矩阵.

用 Lagrange 乘子法, 求式 (10) 的条件极值. 引入参数 $\lambda$, 考虑

$$
\boldsymbol{z}=\boldsymbol{\omega}^{\mathrm{T}} \boldsymbol{R}_{x x} \boldsymbol{\omega}+\boldsymbol{\lambda} \boldsymbol{\omega}^{\mathrm{T}} \boldsymbol{U}
$$

求偏微商, 得到

$$
\frac{\partial \boldsymbol{z}}{\partial \boldsymbol{\omega}}=2 \boldsymbol{R}_{x x} \boldsymbol{\omega}+\boldsymbol{\lambda} \boldsymbol{U}
$$

令式 (13) 为 0 , 求出

$$
\boldsymbol{\omega}_{\mathrm{opt}}=-\boldsymbol{\lambda} \boldsymbol{R}_{x x}^{-1} \boldsymbol{U} / 2
$$

再用约束条件求解 $\lambda$, 得到

$$
\boldsymbol{\omega}_{\mathrm{opt}}=\frac{\boldsymbol{R}_{x x}^{-1} \boldsymbol{U}}{\boldsymbol{U}^{\mathrm{T}} \boldsymbol{R}_{x x}^{-1} \boldsymbol{U}}
$$




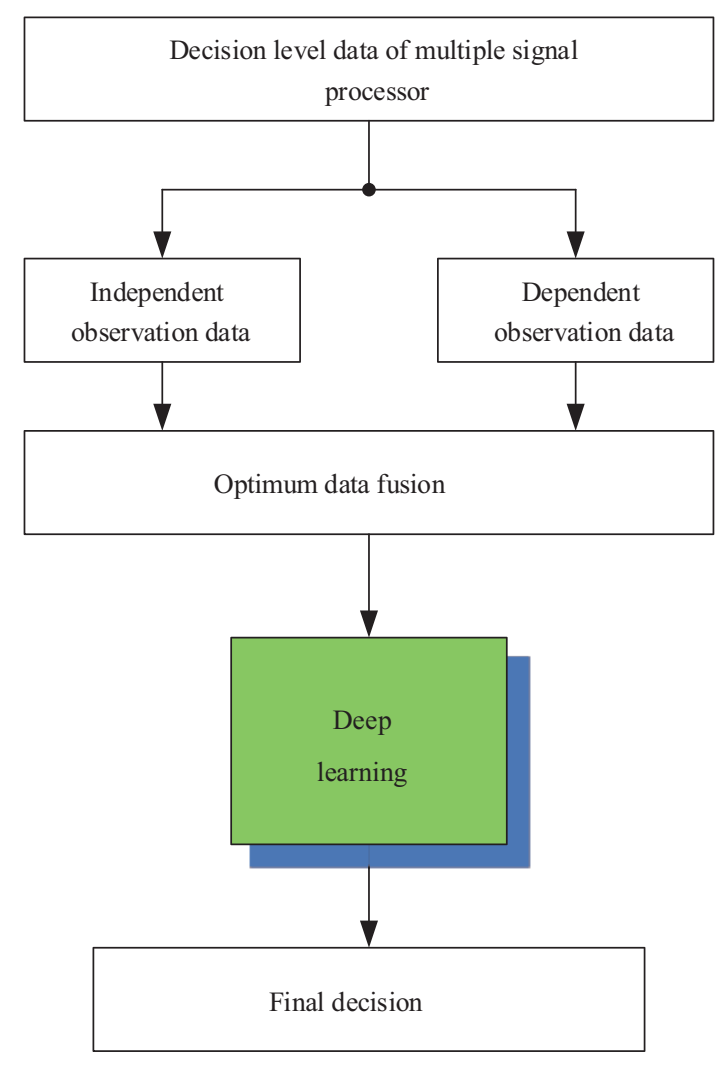

图 3 (网络版彩图) 深度学习算法在数据融合中的应用

Figure 3 (Color online) Block diagram of application of deep learning algorithm in data fusion

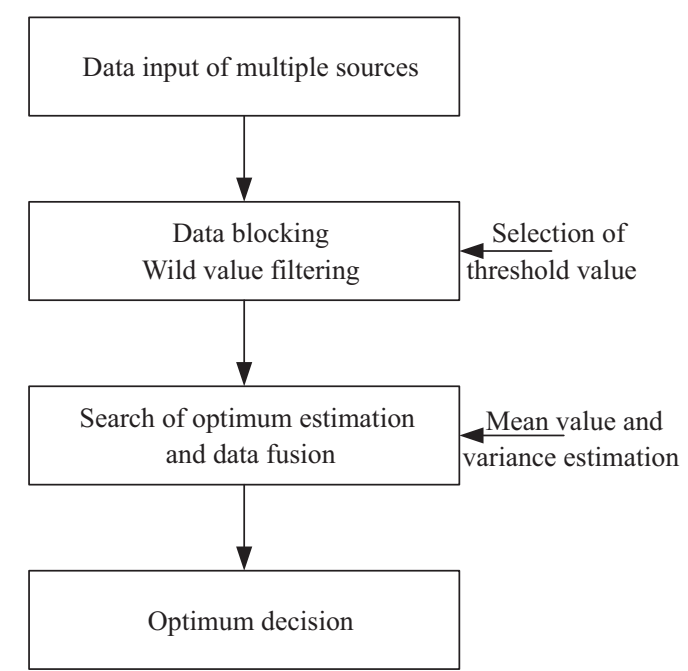

图 4 深度学习算法方框图

Figure 4 Block diagram of deep learning algorithm in data fusion

$$
\boldsymbol{I}_{\mathrm{min}}=\boldsymbol{I}\left[\boldsymbol{\omega}_{\mathrm{opt}}\right]=\frac{\boldsymbol{\omega}_{\mathrm{opt}}^{\mathrm{T}} \boldsymbol{R}_{x x} \boldsymbol{\omega}_{\mathrm{opt}}}{\boldsymbol{U}^{\mathrm{T}} \boldsymbol{R}_{x x}^{-1} \boldsymbol{U}}
$$

可以证明 ${ }^{[5,6]}$, 对任何 $i$

$$
\boldsymbol{I}_{\text {min }}=\boldsymbol{I}\left[\boldsymbol{\omega}_{\mathrm{opt}}\right] \leqslant \operatorname{Var}\left(x_{i}\right)=\sigma_{i}^{2}, \quad i=1, \ldots, N,
$$

也就是说, 不管观测数据的数量有多少, 不管观测资料是独立的还是相关的, 最佳线性融合的结果从 统计平均意义上来说, 比任何单个观测量的估计误差都要小.

\section{3 一种深度学习在数据融合中的应用}

图 3 给出了深度学习算法在决策级数据融合中的应用的方框图. 我们把有关的深度学习算法嵌 入到数据融合决策级之中. 在做出最终决策之前, 由输入的数据进行学习训练, 剔除有可能的野值, 并 对数据进行分块. 再寻求最佳的数据融合. 计算框图见图 4 .

图 5 给出了系统模拟的结果, 对一批 300 个观测数据进行数据融合和深度学习处理. 假定目标的 方位在 $25.6^{\circ}$, 对该目标方位进行估计, 单次估计误差的均方根值为 $0.4^{\circ}$.

野值过滤是深度学习在第 1 阶段的运算, 可以采用阈值滤波, 中位数滤波或均值滤波去剔除野值. 这实际上也是一个学习的过程, 如果我们关注的是过滤前后数据的相似性, 那么阈值滤波不失为一种 

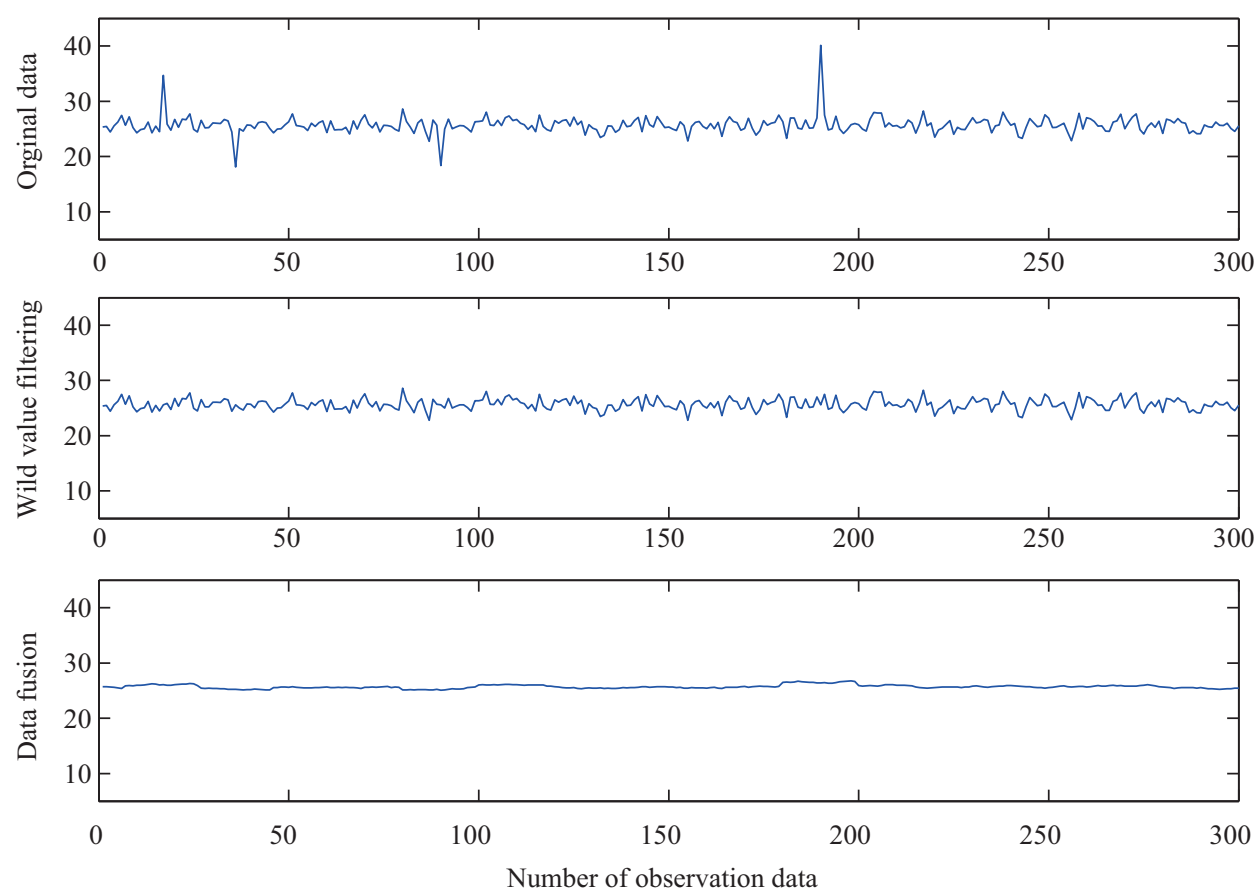

图 5 (网络版彩图) 深度学习: 野值过滤和数据融合

Figure 5 (Color online) Deep learning: wild value filter and data fusion

好的选择. 本文就是选择一种逐点的阈值滤波算法.

分块大小的划分, 依赖于对大批量数据的反复处理, 主要根据分块之后, 数据均值、方差起伏量的 测试, 这也是需要由外界干预调节的. 从我们系统模拟试验的结果来看, 效果还是不错的. 最后数据融 合的结果, 使估计均方差下降到原来的十分之一左右.

\section{4 结论}

声呐信号处理和声呐设计都面临应用人工智能理论和技术的机遇. 人工神经网络理论自 20 世纪 60 年代提出以来, 发展比较缓慢, 直到 2006 年 Hinton 等 [10] 提出深度学习算法之后, 才有了较快的 进展. 声呐信号处理所涵盖的丰富内容可以为人工智能注入新的活力, 开辟新的应用领域, 并丰富人工 智能理论和应用范围.

本文是企图把深度学习的基本概念引入声呐信号处理的一种尝试. 研究表明, 如果可以用数字表 征来刻画被研究对象, 如参数估计、目标识别、图象识别等, 就可以利用数据驱动的算法, 在一定规则 下, 寻求自我学习, 求得较好的解决.

\section{参考文献}

1 Li Q H. Digital Sonar Design in Underwater Acoustics: Principles and Applications. Berlin: Springer, 2010

2 Sittler R W. An optimal data association problem in surveillance theory. IEEE Trans Mil Electron, 1964, 8: 125-139

3 Hall D L, Llinas J. An introduction to multisensor data fusion. Proc IEEE, 1997, 85: 6-23

4 Sharma R, Pavlovic V I, Huang T S. Toward multimodal human-computer interface. Proc IEEE, 1998, 86: 853-869

5 Li Q H. The optimum linear data fusion of independent observations. Chinese J Acoust, 2001, 20: 18-24 
6 Li Q H. The optimum linear data fusion of dependent observations. Chinese J Acoust, 2001, 20: 97-102

7 Anthes G. Deep learning comes of age. Commun ACM, 2013, 56: 13-15

8 LeCun Y, Bengio Y, Hinton G. Deep learning. Nature, 2015, 521: 436-444

9 Poggio T. Deep learning: mathematics and neuroscience. In: Center for Brains Minds+Machines, 2016. http://cbmm. mit.edu/

10 Hinton G E, Salakhutdinov R R. Reducing the dimensionality of data with neural networks. Science, 2006, 313: 504-507

11 Collobert R, Weston J. Deep learning for natural language processing. In: Proceedings of the 23rd Annual Conference on Natural Information Processing System (NIPS), Vancouver, 2009

\title{
A deep learning algorithm for multiple observation data fusion in sonar system
}

\author{
Qihu $\mathrm{LI}^{1,2^{*}}$, Chonghua WEI ${ }^{1,2} \&$ Shanhua XUE ${ }^{1}$ \\ 1. Institute of Acoustics, Chinese Academy of Sciences, Beijing 100190, China; \\ 2. University of Chinese Academy of Sciences, Beijing 100049, China \\ * Corresponding author. E-mail: lqh@mail.ioa.ac.cn
}

\begin{abstract}
The data fusion of multiple sensor observations is an important topic in sonar design. For multiple array sonar signal processing systems, data fusion problem is often not only the problem of multiple observations of a single array but also the data fusion for multiple arrays. In this paper, the basic principle of data fusion is studied, that is the ensemble observation error of data fusion should be, in the statistical average, no larger error than the error of any individual observation data, which is considered as one of the entities in data fusion, regardless of any trash data addition. In other words, in the data fusion process, the increase of observation data quantities should always result in some advantages in the sense of statistical average meaning. This conclusion is the same as deep learning in artificial intelligence. A deep learning algorithm is proposed in this paper for multiple observation data fusion. The optimum linear weighted combination for the independent or dependent multiple observation data is considered as a method of carrying out decision level data fusion. The wild values are picked up before further data processing, and the input data are segmented into several blocks. Data fusion is performed in each block such that we can get minimum observation error results. The results of the system simulation conducted show that in the case where the observation data are interrupted by the interferences, i.e. the wild value, the deep learning algorithm in data fusion, derived in this paper, can considerably reduce the observation error in decision level data fusion.
\end{abstract}

Keywords sonar signal processing, multiple sensor observations, data fusion, deep learning 


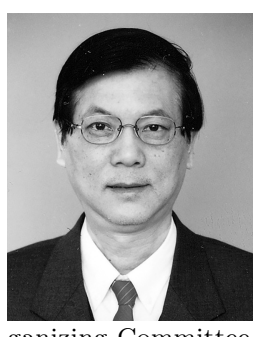

Qihu LI was born in 1939. He obtained a bachelor's degree in 1963 from Peking University. In 1997, he was elected as an academician of the Chinese Academy of Sciences. He is currently a researcher at the Institute of Acoustics, Chinese Academy of Sciences. He is a member of Technical Program Committee of Underwater Defense Technology Conference and Scientific Committee \& Organizing Committee of International Conference On Underwater Acoustics, as well as the deputy director of the advisory board of Chinese "Wisdom Ocean" project. His research interests include acoustics signal processing and sonar design.

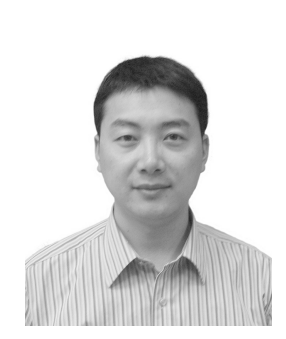

Chonghua WEI was born in 1976. He obtained a Ph.D. degree in 2018 from the University of Chinese Academy of Sciences. Currently, he is an associate professor at the Institute of Acoustics, Chinese Academy of Sciences. His research interests include acoustics signal processing and artificial intelligence.

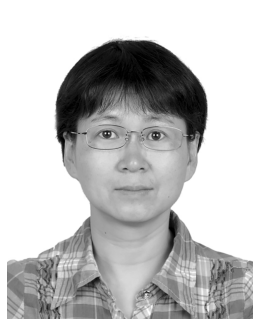

Shanhua XUE was born in 1975. She obtained a master's degree in 2000 from Capital Normal University. Currently, she is an associate professor at the Institute of Acoustics, Chinese Academy of Sciences. Her research interests include acoustics signal processing and artificial intelligence. 